\title{
SABINO, Amadeu Lopes. O todo ou o seu nada. Lisboa: Bizâncio, 2018. 239 p.
}

\author{
MARILENE WEINHARDT \\ Universidade Federal do Paraná (UFPR). Curitiba, PR, Brasil.
}

É lugar comum dizer que esta ou aquela narrativa pode ser lida como se fosse um romance. Em geral, a afirmativa tem o intuito de indicar que se trata de narração de leitura agradável, que se pode fazer sem buscar nada além do prazer de assistir uma realidade tomando forma no discurso linguístico. A leitura de $O$ todo ou o seu nada, de Amadeu Lopes Sabino, romance, conforme registra a folha de rosto, me sugere experimentar inverter a frase: há romances que se pode ler como se não fossem romances. Tomada isoladamente, a formulação é um casuísmo. Afinal, essa é a operação que se realiza na leitura ingênua, que não distingue o acontecimento em si do processo de narrar, e bem por isso quase sempre se limita aos chamados romances de enredo. Ou melhor, limitava-se. Não por acaso esse tipo de leitor está praticamente extinto. Suas necessidades de alimento para o imaginário são satisfeitas pelo cinema comercial e, principalmente, pela produção televisiva, que diversifica progressivamente as ofertas e as formas de acesso, atraindo mais adeptos e acompanhando as alterações do público.

Desde logo, cumpre esclarecer que a ideia da inversão do dito comum não resulta de ter me deparado com texto pouco fluído, de leitura travada, ou qualquer coisa nessa linha. Muito pelo contrário. Comentários sobre as qualidades da narração reservo para mais adiante. Por ora, me detenho em pontos que não são características particulares do discurso romanesco.

O herói é figura empírica, não um "homem comum", como o herói do romance precedente, As claras madrugadas (2015), qualificação que aparece na abertura daquela narração (p.13). Também não tem a dimensão histórica da personagem central de $A$ cidade do homem (2010), o juiz que condenou os inconfidentes mineiros. Embora tenha exercido atividades de escritor, entre tantas outras, o biografado não ocupa posição semelhante, na história da literatura portuguesa, ao lugar de Almeida Garret, em torno do qual gira o enredo de A lua de Bruxelas (2000). Com essas evocações já fica dito que Lopes Sabino tem frequentado com insistência e persistência esse tipo de narrativa que qualifica como "biografia imaginada". Todos esses romances se caracterizam por mergulho profundo em pesquisas, de várias ordens, conforme as exigências de cada escolhido: investigação em documentos, específicos ou não, visita aos espaços geográficos em que viveu a personagem, leituras sobre a época, desde o enquadramento filosófico até os lazeres habituais, passando pela sociologia, pela antropologia e pelo direito. São procedimentos típicos do estudioso das Humanidades, não necessariamente do ficcionista. E confessos, como se pode verificar nos "Créditos" (p.233-239). Esses traços, que perpassam todas as obras citadas, não significam que se tem mais do mesmo. Cada título guarda sua singularidade, sua especificidade, não apenas enquanto tema, também como discurso.

Depois dessa digressão pela produção do autor, volto à primeira frase do parágrafo anterior, me detendo no herói de $O$ todo ou o seu nada. A eleição de personagens empíricas como heróis das obras anteriores não me levou a questionar a inscrição no gênero romanesco, a despeito do referido rigor do método de pesquisa. É verdade que discordamos, o autor e eu, quanto à qualificação, uma vez que os leio como romances históricos, adotando conceituação do subgênero não subscrita por ele, que tem aturada reflexão sobre a proximidade e os limites entre narrativa histórica e narrativa ficcional, como se pode perceber, entre outros escritos seus, no primeiro parágrafo dos referidos "Créditos" (p.233-234). A propósito, abro um parêntese provocativo: O todo ou o seu nada não é romance histórico, tout court, mas certamente é possível lê-lo como ficção histórica. As circunstâncias de um tempo histórico que sofre profundas alterações estão registradas, a vida do protagonista e a vida do narrador-personagem são afetadas por tais circunstâncias de maneira decisiva. Parêntese fechado.

Quanto à personagem central do romance, João Falcato foi professor de Lopes Sabino no colégio, seu amigo ao longo da vida, com períodos de maior ou menor convívio, conforme os acasos da vida de cada um. O livro é uma homenagem, um preito de gratidão e admiração, 
uma declaração de afeto, um canto de louvor àquele que o autor elegeu como mentor.

Homenageado, mentor, nem por isso a personagem é apresentada como modelo de perfeição. Não é um ídolo para Lopes Sabino. Aliás, idolatrar quem quer que seja seria uma traição a suas lições. Singular, diferenciado, mas humano, muito humano, é o modo de ser multifacetado de João Falcato que seduz o escritor. Este se faz presente na narrativa sem disfarces, como narrador e também como personagem. $\mathrm{O}$ aluno, a origem familiar, o estudante engajado em atividades políticas, o rapaz casadoiro, o jovem pai, o dissidente, o escritor que se inicia na atividade jornalística, o desertor das guerras coloniais, o exilado, o funcionário da União Europeia que visita a terra natal esporadicamente, enfim, o leitor tem acesso também à trajetória pessoal do autor, pontuando a história da vida do outro, ou melhor, pontuando o relacionamento. A biografia é construída colocando em evidência a quebra da norma, a excentricidade, a capacidade de questionamento do estabelecido, o desejo de conhecer o diferente, a ousadia, ainda que alguns passos se deem em falso, características que distinguem a personagem. $\mathrm{O}$ percurso inusitado de quem não se entrega à convenção é a tônica do romance.

Sim, romance. Comecei brincando com a ideia de tomar o dito popular pelo avesso, mas é o discurso romanesco que avulta, apropriando-se do discurso biográfico e do discurso autobiográfico. Quem conheceu João Falcato pessoalmente pode se interessar por um ou outro episódio, pode confirmar esta ou aquela passagem ou questionar o relato ao confrontá-lo com as próprias memórias. Mesmo quem não teve a oportunidade desse convívio, mas experimentou o clima social e político de Portugal da época, pode encontrar na leitura o interesse da reminiscência. Mas para nós, leitores que não participamos daquele universo, João Falcato é personagem interessante porque construída pela maestria do romancista. É o modo como se apresenta o agenciamento a narrativa que nos leva a percorrer mais de duas centenas de páginas sem que o interesse esmoreça, embora saibamos, desde as primeiras linhas, que o protagonista já morreu.

Um romance bem realizado leva o leitor a retornar ao primeiro parágrafo quando chega ao último. Nesta leitura, ao realizarmos esse movimento de olhos e mãos, nos damos conta como o universo ficcional se fecha harmoniosamente. Antes de remontarmos ao início, encarecendo o cuidadoso fechamento da narrativa, convém observar que próximo ao final, cinco páginas antes do desfecho, explica-se a epígrafe, uma passagem de Platão em que Sócrates, moribundo, recomenda ao discípulo: "nós devemos um galo a Asclépio. Satisfaz essa dívida e não te descuides!" (s/p.). A fala repete-se, no último encontro entre João e Amadeu. Apresentada assim, isoladamente, a cena pode parecer pedante, mas é a confirmação de pista que pontua a narrativa, a orientação filosófica que o mestre legou ao discípulo. Essa conversa derradeira é pontuada por referências literárias e filosóficas, dando a medida do relacionamento entre os interlocutores. Poucas linhas adiante, o título da narrativa, "a divisa outorgada por Agostinho da Silva" (p. 169), emprestada "de um verso do inevitável Pessoa" (p. 236), referida em passagens anteriores, reaparece com pequena variação, na voz de Falcato, como corolário de romance que não chegou a escrever: " - Melhor: o todo $e$ o seu nada . Prefiro a cupulativa à disjuntiva. Adiciono" (p.225). A promessa que não se realiza, o potencial que não se concretiza em outra obra depois da promissora estreia com Fogo no mar, o desafio não satisfeito é questão que permeia o romance.

O relato do episódio específico, esse encontro, comporta a fidedignidade de quem vivenciou o fato, dividindo o protagonismo. Muitas passagens trazem transcrições diretas, de trechos de autoria de Falcato ou sobre ele. Por vezes é a análise de dados que permite ao narrador inferir o que aconteceu. Serve de exemplo a explicação para o leitorado na Alemanha: "Pela dedicatória terá sido dele [João Pereira Dias, diretor-geral do ensino superior e secretário-geral do ministério] o voto decisivo para a atribuição do leitorado a um professor do ensino secundário particular, licenciado em Histórico-Filosóficas e não em Filologia, como era habitual" (p. 96). Em outros momentos há suposição, como ilustra a passagem: "Em A Alemanha actual [um dos títulos publicados por Falcato] há um elogio à mulher alemã: sinfonia de olhos azuis, pele de cetim, moldura de oiro. Será Ulla Baum o modelo deste retrato?" (p. 83). O verbo "presumo" ocorre eventualmente. No entanto, quando se depara com falta de fontes o narrador, romancista que é, não recua: "Pois que me encontro no domínio da ficção, imagino a estância de João Falcato no Recite para além do dia 21 de outubro de 1943...” (p. 145). Esse nível de explicitação do processo não ocorre com frequência. Amadeu Lopes Sabino não é adepto da insistência na metaficção, tendência tão frequentada na contemporaneidade. No entanto, não ignora que esse procedimento, o preenchimento dos vazios entre os fatos, nos libera de ler uma biografia enquanto tal, escrita que é um meio que tem seu interesse fora do texto, para adentramos e nos entregarmos a narrativa cujo significado independe de circunstâncias exteriores.

Referi a amarração entre abertura e fecho coroando o romance. Retorno ao longo primeiro parágrafo, que sumariza a vida de Falcato, destacando-se a constância da atividade da escrita. Centralizado na morte da personagem, contém metáforas para designar o fim da vida que dizem do repertório cultural do autor: "partiu para as paragens ignotas a que chamamos o Além"; "corredor de paredes 
translúcidas que, dizem os entendidos, conduz o recémfalecido até às portas do reino obscuro onde receberá pousada" (p. 11); "entrar na barca do esquecimento, onde as Parcas apagam as memórias da vida na Terra" (p. 12). Aparece nessa altura pela primeira vez a referência que, na minha leitura, funciona como epicentro da narrativa: a autoria de "Fogo no mar, relato do incêndio e naufrágio no Atlântico do cargueiro Mello, durante a Segunda Guerra Mundial" (p. 12). Certamente, a experiência vivida então terá marcado o indivíduo. Mas é o fato de tê-la transposto para a escrita que Lopes Sabino coloca em evidência. As circunstâncias históricas do naufrágio mesmo aparecem no derradeiro dos nove capítulos.

O parágrafo inicial merece mais dois destaques, por bem exemplificarem o tipo de requinte linguístico e narrativo que permeia toda a obra. Tratando da morte da personagem, não há ocorrência do verbo morrer e o substantivo morte só aparece na passagem uma vez, e não se refere à morte de fato. $\mathrm{O}$ "rosto da morte" é visto no naufrágio. Quanto ao modo de selecionar descrições e informações, vale notar a caracterização física. Nesse primeiro contato, o leitor tem a imagem da cabeça, em dois momentos: "a cabeleira, de um fulvo majestoso antes do arminho dos anos do fim" (p.12). Ao longo da narrativa os traços físicos são disseminados, conforme a oportunidade, eventualmente aproveitando para marcar as transformações decorrentes da passagem do tempo. A idade precisa aparece também por duas vezes nesse trecho: inicialmente o desaparecimento, aos 90 anos e, linhas adiante, a publicação do livro em 1945, aos 30 anos. Datas não são registradas com destaque. Ainda que romance biográfico, cabe ao leitor fazer as contas.

É no trabalho de recorte e montagem do tempo, dos acontecimentos, das informações sobre o modo de ser da personagem e do próprio autor que a arte do romancista melhor se evidencia, ou antes se esconde. As junções não se deixam ver ao primeiro olhar, a linha cronológica é sinuosa, com antecipações e recuos, com retomadas e saltos à frente, permeada por análises sobre a época, sobre a política, sobre os costumes, sobre a economia, sobre a nação, fundindo e confundindo a voz da personagem e do autor, muitas vezes em tom ensaístico. Afinal, não por acaso João Falcato é escolhido por Amadeu Lopes Sabino como seu mentor. O leitor fica conhecendo as circunstâncias biográficas de ambos, também o percurso intelectual e, especialmente, o modo de ver o mundo. Discurso biográfico e discurso autobiográfico não são apropriados pelo romance em pé de igualdade, mas a dose de autobiografia não é de pouca monta na composição. Eleger uma "figura fundadora" (p. 200) não é se fazer à sua imagem e semelhança, é confessar a influência e também marcar as diferenças, assim conhecendo a sim mesmo.

Recebido: $11 / 12 / 2018$

Aprovado: 21/12/2018

Autora:

MARILENE WeINHARDT

Professora. Universidade Federal do Paraná (UFPR/CNPq)).

Curitiba, PR, Brasil

mweinhardt@gmail.com 